\title{
Determination of Factors Effected Dietary Glycemic Index in Turkish University Students
}

\author{
Huseyin Gumus $^{1 *}$, Yasemin Akdevelioglu ${ }^{2}$, and Sidıka Bulduk ${ }^{3}$ \\ ${ }^{I^{*}}$ Faculty of Tourism, Gastronomy and Culinary Arts Department. 06830 Golbasi, Ankara, Turkey. \\ ${ }^{2}$ Faculty of Health Sciences, Department of Nutrition and Dietetics. Gazi University, 06500 Besevler, \\ Ankara, Turkey \\ ${ }^{3}$ Faculty of Vocational Education, Food and Nutrition Department. Gazi University, 06500 \\ Teknikokullar, Ankara, Turkey \\ *E-mail: huseyingms@gmail.com
}

\begin{abstract}
We aimed to determine any factors like as smoking, being regular activity ect. effected on dietary glycemic index in university students. Methods: This study was carried out at Gazi University, Ankara, Turkey. The participants were 577 randomly selected Turkish healthy female university students aged 17-32 years. The survey included a questionnaire that assessed demographic, 3-day self-reported nutrient intake. The dietary intake was based on the of the recipients. The 3 days included 1 weekend day and the previous or next 2 days (Sunday, Monday, Tuesday or Thursday, Friday, Saturday). A weighted GI was designed to the diet of the participants with the use of values from the 2002 international table of GI values. BMI was calculated from measurements of height and weight. The differences between living area (house or dormitory)/ regular pysical activity (do or not)/smoking/nutrition education and mean dietary glycemic index was determined by Independent Sample t-Test. Results: Dietary glyemic index was found high (>70) in $98.4 \%$ of participants. Mean dietary glycemic index was found $85.1 \pm 6.80$ and it was significantly $(\mathrm{p}<0.05)$ differences between participants staying house or dormitory, doing physical activity or not, smoking or not and educated on nutrition or not. Participant's who are smoking, staying dormitory, sedanter and no educated about nutrition dietary glycemix index was found high than who are not smokin, staying house, doing regular physical activity and educated on nutrition. Conclusion and Implication: It's important that educated students on health and nutrition to prevent their diets content high glycemic index. It can be help to prevent obesity in the future.
\end{abstract}

Key Words: glycemic index, diet, adolescent

ISSN 2165-8714

Copyright (C) 2014 EU-JER

http://www.eu-jer.com DOI: 10.12973/eu-jer.3.1.1 


\section{INTRODUCTION}

Glycemic Index (GI) is the assessment of the effects of the nutrients containing carbohydrate on blood glucose. GI is generally defined as the area under glycemic answer curve for 2 hours after the consumption of test meal containing $50 \mathrm{~g}$ of carbohydrate. GI of some food is high. These are food with a high refinery carbohydrate content (the effect of fat and protein on blood glucose is at the minimal level compared to carbohydrate), food with high level of lactose (contains high level of glucose and/or starch compared to sucrose and fructose), food with a low level of pulp content solvable in water (pulp solvable in water forms a kind of gel in stomach and increases the speed of gastric excretion and decreases digestion) and food in soft, overcooked, over processed and ripe form (as they are more rapidly digested compared to raw, non-processed food) (1).

There have been a great many researches suggesting that total fat and saturated fat intake increases the risk factors of cardiovascular diseases. However, there are few studies on carbohydrate level of diet and disease risk. It was found that carbohydrates have mid level effect on postprandial glucose and insulin responses and that plasma TG levels increase and LDL particle size and emission speed increases with the replacement of carbohydrates with saturated fats at diet. It is likely to say that other metabolic effects are related to visceral fatness and decrease at hyperinsulinemia and insulin sensibility. Although there is much focus on the consumption of whole cereal, fruit and vegetable consumption within typical dieting recommendations, there are very limited number of studies examining the relationship between disease risks and cereal consumption. In a study by Iowa Women Health, it was found that the rates of cancer and cardiovascular diseases decreased at women consuming diets rich in whole cereal compared to those consuming less diet rich in whole cereal or consuming more refined cereals. Although the energy of the diet rich in whole cereal products is high, it is associated with low BMI and waist/hip rate (2).

Traditional dieting approaches mostly result in disappointment for the treatment of fatness. In a study carried out to compare the effectiveness of a low GI diet and the diet where standard fat is decreased on pediatric obese people, it was found that BMI and body mass of those consuming a GI diet is lower compared to the ones consuming diets with a reduced standard fat. It was pointed out that low GI diets could be an alternative to the treatment of diets with a standard reduced fat at obese children; however, there is a need to long term controlled studies aiming at determining the effects of it on the treatment and prevention of the disease (3).

There are a number of researches carried out over the effect of GI on appetite. Louis, Sylvestine and Le Megnan (4) and later on Smith and Campfield (5) found in their studies that there is a relationship between the desire for nutrients and the decrease at the blood glucose. These observations revealed that the consumption of food with a high GI increased the formation of feeling hungry compared to low GI food with the same level of energy, as constant decrease of blood glucose from the level it had the highest after the consumption of high level GI food results in excessive hormonal response which allows the high glucose level in this circulation to turn into normal. Additionally, high level insulin in the circulation could be related to the consumption of high level GI food that put a pressure on the mobilization of fat from adipose tissue. With the consumption of high glycemic index food, the level of fat acid in the circulation decreased. The fact that high blood glucose decreased the feeling of being hungry was proved in the researches (6-8).

The difference of the glycemic response caused by individual differences is underestimated for some data today; whereas, the reason of different glycemic responses for the same nutrient could be explained through individual differences. It is known that both normal weight people and overweight people have a high level of susceptibility for the side effects of high GI diet. Metabolic response for high GI food decreased in the groups made up of people with a high activity, as insulin vulnerability is known to be affected by exercises thoroughly. Insulin susceptibility is higher in sedentary people than those having a higher activity. The increase in the insulin susceptibility leads to decrease at the glucose levels caused by the digestion of carbohydrates and drop of blood glucose after $60-120$ minutes later meals slowly. At the same time, there are genetic factors believed to have an effect on insulin susceptibility (9).

A considerable part of higher education students carry on their education far from their families and such a case cause some trouble in their nutrition, accommodation, school expenditure, social status, leisure time activities and health problems. Nutrition is particularly a problem for those living 
at dormitory houses $(10-12)$. This study was carried out to determine the factors affecting glycemic index levels of university student diets.

\section{MATERIAL AND METHOD}

A total 577 healthy girl students at the age of $18-30$ (mean $21.2 \pm 2.0$ ) having an education of undergraduate at different departments of Gazi University, Faculty of Vocational Education in Ankara were included in the study.

\section{Anthropometric data}

BMI was calculated from measurements of height and weight. Participants were classified according to body mass index (BMI); BMI 18.5 to $24.9 \mathrm{~kg} / \mathrm{m}^{2}$ were classified as normal weight, 25 to $29.9 \mathrm{~kg} / \mathrm{m}^{2}$ as overweight, and $30 \mathrm{~kg} / \mathrm{m}^{2}$ or greater as obese.

\section{Questionnaire information}

The survey included a questionnaire that assessed demographic, 3-day self-reported nutrient intake. The dietary intake was based on the of the recipients. The 3 days included 1 weekend day and the previous or next 2 days (Sunday, Monday, Tuesday or Thursday, Friday, Saturday). Adolescents are professional to complete the form of nutrition dietary intake. Adolescents record everything they eat and drink, and water during this 3-day period. They were asked to provide as much information as possible about serving size (eg, portion, cup, mug tea glass, teaspoon, dessert spoon, table -spoon), method of cooking (eg, boiled, grilled, fried), and all details of food consumption. The average energy, carbohydrate, fiber, percentage of energy from carbohydrate, percentage of energy from fat, content for each individual's diet were analyzed by nutrient database program designed to calculate the nutritional value of Turkish food and commercial products.

\section{Assesment of glycemic index}

A weighted GI was designed to the diet of the participants with the use of values from the 2002 international table of GI values (13). Daily dietary glycemic index and glycemic load were calculated from the 3 day dietary recall. Glycemic index is a measure of the quality of carbohydrates in foods and of glycemic response. The recommended formulas (14) for calculating overall dietary glycemic index is the following:

Overall dietary glycemic index $=[($ Carbohydrate content of each food item $) X($ number of servings/d) X (GI)]/total daily carbohydrate intake

White bread was used as the reference.

\section{FINDINGS AND DISCUSSION}

Table 1. Diet parameters of Girl Students $(n=577)$

\begin{tabular}{lccc}
\hline Diet Parameters & $\mathbf{X}$ & Min & Max \\
\hline Total energy (kcal/day) & $1427.1 \pm 564.40$ & 4236.6 & 114.3 \\
CHO (\%) & $41.7 \pm 10.10$ & 10.7 & 76.5 \\
Fat (\%) & $43.7 \pm 9.90$ & 8.8 & 69.8 \\
Pulp (g/day) & $15.4 \pm 7.50$ & 0.73 & 44.69 \\
Glycemic Index & $85.1 \pm 6.80$ & 52.9 & 100.02 \\
\hline
\end{tabular}


As given in Table 1, average energy amount students take through diet was $1427.1 \pm 564.40 \mathrm{kcal} /$ day, the percentage of energy coming from carbohydrates was $41.7 \pm 10.10$, the one coming from fats was 43.7 \pm 9.90 , daily pulp intake was $15.4 \pm 7.50 \mathrm{~g}$ and GI level of diet was found as $85.1 \pm 6.80$. In the studies carried out over $18-24$ years of age youth, it was found that energy intake, particularly for girls, was below the recommended values $(15-23)$. It was also found in our study that energy intake of girls in our country was $65 \%$ of the recommended value. Ideal recommendations for daily energy coming from carbohydrate and fat were $55-60 \%, 25-30 \%$ respectively (24). In this case, it is clear that the percentages of energy of students coming from fat were high, but the ones coming from carbohydrates were low. In another study conducted over university students (23) it was expressed that high fat intake of girls compared to that of boys resulted from the fact that girls didn't usually eat at school restaurant and that they preferred diet one of the snacks like biscuits, hamburger, toast and sandwich accompanied by diet coke for lunch instead, but that boys mostly had their lunch at school restaurant. In another research (25), it was found that fast food consumption among students was high and chocolate, bakery and biscuits consumption for snacks was also high. It was determined in our study that food high in glycemic index consumed by students mostly were white bread, pasta, potato, sugar, chocolate, coke drinks, biscuits and sandwich from the highest to the lowest. It reveals that students applied a type of diet rich in refinery carbohydrates.

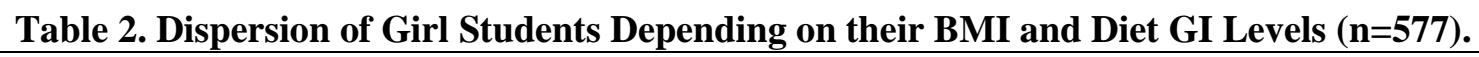

\begin{tabular}{lcc}
\hline & S & \% \\
\hline Body Mass Index $\dagger\left(\mathrm{Kg} / \mathrm{m}^{2}\right)$ & & \\
Slimness $(<18.5)$ & 75 & 13.0 \\
Normal $(18.5-24.9)$ & 460 & 79.7 \\
Overweight $(25-29.9)$ & 42 & 7.3 \\
\hline Dietary GI level & & \\
Low $(<55)$ & 1 & 0.2 \\
Medium $(55-69)$ & 8 & 1.4 \\
High $(>70)$ & 568 & 98.4 \\
\hline
\end{tabular}

$\dagger$ Weight $(\mathrm{Kg}) /$ Height $(\mathrm{m})^{2}$

Depending on BMIs of girl students included in the study, $79.7 \%$ of their body mass was found normal. Similar studies supported this finding. In some studies $60.3 \%-82.3 \%$ of BMIs of girl students attending to a university was found normal. In the current study, $13.0 \%$ of students were found slim, while $7.3 \%$ of them were found overweight. Glycemic index levels of the diets of almost all girl students (98.4\%) were found high (>70). Küçükerdönmez et al., (26) found in a study of theirs carried out on overweight individuals glycemic index level of 18 individuals were high. In a study which is conducted by Rauhani et al. (27) it is determined that there is not a meaningful change in the body weight and blood pressure of the girl adolescants who are fed by low glycemic index diet for ten weeks and concluded that long-term studies should be done. 
Table 3. Mean Scores of Glycemic Index Levels of Girl Students Depending on their Accommodation, Status of Smoking, Status of Doing Sport and Status of Taking Nutrition Education $(\mathbf{n}=577)$

\begin{tabular}{|c|c|c|c|c|c|c|}
\hline \multirow[b]{2}{*}{ Vairables } & \multirow[b]{2}{*}{$\mathbf{n}$} & \multirow{2}{*}{$\begin{array}{c}\text { GI Level of } \\
\text { Diet } \\
\text { X } \\
\end{array}$} & \multicolumn{2}{|c|}{ Levene's Test } & \multicolumn{2}{|c|}{ t-Test } \\
\hline & & & $\mathbf{F}$ & $\mathbf{P}$ & $\mathbf{t}$ & $\mathbf{p}$ \\
\hline \multicolumn{7}{|l|}{$\begin{array}{l}\text { The Place they } \\
\text { accommodate }\end{array}$} \\
\hline Home & 309 & $84.4 \pm 6.82$ & \multirow[t]{2}{*}{0.031} & \multirow[t]{2}{*}{0.860} & \multirow[t]{2}{*}{2.521} & \multirow[t]{2}{*}{0.012} \\
\hline Boardin House & 268 & $85.8 \pm 6.72$ & & & & \\
\hline \multicolumn{7}{|l|}{ Status of Smoking } \\
\hline Smoking & 64 & $87.2 \pm 8.09$ & \multirow{2}{*}{3.110} & \multirow{2}{*}{0.075} & \multirow{2}{*}{2.627} & \multirow{2}{*}{0.009} \\
\hline Non-smoking & 513 & $84.9 \pm 6.58$ & & & & \\
\hline \multicolumn{7}{|c|}{ Status of Doing Regular Sport } \\
\hline Doing & 96 & $83.6 \pm 7.17$ & \multirow{2}{*}{0.071} & \multirow{2}{*}{0.790} & \multirow{2}{*}{-2.445} & \multirow{2}{*}{0.015} \\
\hline Not doing & 481 & $85.4 \pm 6.69$ & & & & \\
\hline \multicolumn{7}{|c|}{ Status of Taking Nutrition Education } \\
\hline Taken & 299 & $84.5 \pm 6.84$ & \multirow{2}{*}{0.053} & \multirow{2}{*}{0.818} & \multirow{2}{*}{5.626} & \multirow{2}{*}{0.018} \\
\hline Not taken & 278 & $85.8 \pm 6.69$ & & & & \\
\hline
\end{tabular}

As shown in Table 3, GI levels of diets had significant difference depending on their accommodation, status of smoking, status of doing sport and status of taking nutrition education $(\mathrm{p}>0.05)$. It was that those living at home had lower diet GI levels compared to those living at dormitory houses. It was suggested in the study that those living at home had minor nutrition problems $(28,29)$ and nutrition of those living in dormitory houses were less regular than that of the ones living

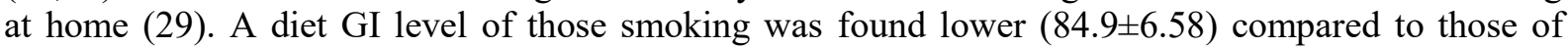

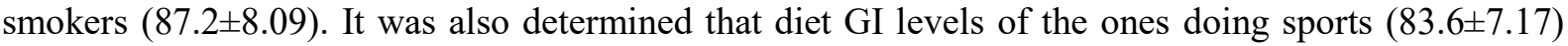
were lower than those not doing $(85.4 \pm 6.69)$ and that diet GI levels of those having taken nutrition education (84.5 \pm 6.84$)$ were lower than those of the student not having taken such an education (85.8 \pm 6.69$)$. It shouldn't be underestimated that the existence of such could lead to the increase at the glycemic index of the diets of students and following that it could result in the problem of being overweight. We recommend that the facilities of accommodation of students should be improved, there should be more sportive complexes for a regular sport, everything should be done not to allow them acquire the habit of smoking and take a nutrition education.

\section{CONCLUSION AND RECOMMENDATIONS}

Smoking, not doing regular sport, staying at a dormitory house and not having taken a nutrition education could lead to the fact that students mostly prefer nutrients high in glycemic index and so to the increase at their glycemic index levels in their diets. It is of great importance students be offered sufficient and healthy food and nutrition education as well as food preferences at dormitory houses be used in favor of healthy food. It is considered that taking these precautions would allow to reduce the risk of becoming overweight in the future. 


\section{REFERENCES}

1. Ludwig DS. Dietary glycemic index and obesity. J. Nutr. 2000; 130:280S-283S.

2. Wolever TMS. Relationship between dietary fiber content and composition in foods and the glycemic index. Am. J. Clin. Nutr. 1990;51:72-5.

3. Ludwig D. Majzoub J.A, Al-Zahrani A, Dallal G.E, Blanco I. Roberts S.B. High glycemic index foods, overeating, and obesity. Pediatrics. 1999; 103(3):e26.

4. Louis Sylvestre J. Le Megnan J.A fail in blood glucose level precedes meal onset in free feeding rats. Neurosci Biobehav Rev. 1993; 4:13-5.

5. Smith FJ. Campfield LA. Meal initiation occurs after experimental induction of transient declines in blood glucose. Am. J. Physiol.1993; 265:R1423-9.

6. Campfield LA. Smith FJ. Rosenbaum M. Hirsch J. Human eating evidence for a physiological basis using a modified paradigm. Neurosci Biobehave Rev. 1996; 20:133-7.

7. Chapman IM. Goble E.A. Wittert G.A. Morley J.E. Horowitz M. Effect of intravenous glucose and euglycemic insulin infusions on short term appetite and food intake. Am. J. Physiol. 1998; 274: R596-603.

8. Gielkens HA. Verkijik M. Lam WF. Lamers CB. Masclee AA. Effects of hyperglycemia and hyperinsulinemia on satiety in humans. Metabolism. 1998; 47:321-324.

9. Roberts SB. High Glycemic Index Foods, Hunger, and Obesity: Is there a connection? Nutrition Reviews. 2000; 58(6): 163-169.

10. Arslan, P. Pekcan G. Yurtta Kalan Yüksek Öğrenim Gençlerinin Beslenme Durumları ve Sorunları Diabet Yıllığı 4. Temel Matbaası İstanbul. 1985.

11. Iş1ksoluğu M.Yüksek Öğrenim Gençliğinin Beslenme Sorunları. Fırat Havzasında Yükseköğretim 1987; 247-258.

12. Sağlam F. Yürükçü S. Ankara Üniversitesi Eğitim Bilimleri Fakültesi Yüksek Okul Öğrencilerinin Besin Tüketim Durumu, Beslenme Alışkanlıkları ve Beslenme Bilgi Düzeylerinin Saptanması. Beslenme ve Diyet Derg. 1996; 25: 16-23.

13. Foster-Powell K, Holt SHA, Brand-Miller JC. International table of glycemic index and glycemic index load values: 2002. Am. J. Clin. Nutr. 2002; 75:5-56.

14. Pi-Sunyer FX. Glycemic index and disease. Am J Clin Nutr 2002;76:290S-8S. [PubMed: 12081854].

15. Anding JD, Suminski RR, Boss L. Dietary intake, body mass index, exercise, and alcohol: are college women following the dietary guidelines for Americans. J Am Coll Health 2001; 49:167- 171.

16. Çelik F, Toksöz P. Dicle Üniversitesi Beden Eğitimi ve Spor Bölümünde okuyan öğrencilerin besin tüketim düzeyleri ve beslenme alışkanlıkları. Beslenme ve Diyet Derg. 1999; 28:4-9.

17. Fregapane G, Asensio-Garcia C. Dietary assessment of an educated young Spanish population using a self-administered mealbased food frequency questionnaire. Eur J Epidemiol 2000; 16:183-191.

18. Hampl JS, Betts NM. Comparisons of dietary intake and sources of fat in low-and high-fat diets of 18-to24-year-olds. J Am Diet Assoc 1995; 95:893-897.

19. Kimura N, Fukuwatari T, Sasaki R, Hayakawa F, Shibata K. Vitamin intake in Japanese women college students. J Nutr Sci Vitaminol 2003; 49:149-155.

20. Mammas I, Bertsias G, Linardakis M, Moschandreas J, Kafatos A. Nutrient intake and food consumption among medical students in Greece assessed during a Clinical Nutrition Course. Int J Food Sci Nutr 2004; 55:17-26.

21. Quiles JL, Manas M, Martinez MA, Ochoa JJ, Yago MD, Ramiez- Tortosa MC, Carazo E, Martinez-Victoria E. Dietary intake and anthropometric measures in a Spanish students group. Internat. J Vit Nutr Res 1996; 66:371-377.

22. Soriano JM, Molto JC, Manes J. Dietary intake and food pattern among university students. Nutr Res 2000; 20:1249-1258.

23. Garibağaoğlu M, Mergen Ö, Öner N. Fizik tedavi ve rehabilitasyon yüksekokulu öğrencilerinin ağırlı durumları ile beslenme alışkanlıklarının değerlendirilmesi, İstanbul Üniversitesi İstanbul Tıp Fakültesi Derg. 2005; 68 (3): 64-70. 
24. Dietary guidelines: Past experience and new approaches. April 30-May 1, Toronto, Canada. Proceedings of a Symposium. J. Am.Diet. Assoc. 2003; 103 (Suppl 2):3-9.

25. Güleç M, Yabancı N, Göçgeldi E, Bakır B. Ankara'da iki kız öğrenci yurdunda kalan öğrencilerin beslenme alışkanlıkları, Gülhane Tıp Dergisi 2008;50: 102-109.

26. Küçükerdönmez Ö. Özel Gökmen H. Köksal G. Gök Engin D. Kutlu M. Şişman bireylerde diyetin glisemik indeksinin antropometrik ve biyokimyasal parametreler üzerine etkileri. VI. Uluslararas1 Beslenme ve Diyetetik Kongresi, 2008; 339, Antalya.

27. MH. Rauhani, Kelishadi R, Hashemipour M, Esmaillzadeh A, Azadbakht L. The effect of low glycemic index diet on body weight status and blood pressure in overweight adolescent girls: a randomized clinical trial. Nutr Res Pract. 2013 October; 7(5): 385-392.

28. Köksal O. Üniversite gençliğinin beslenme konusu ve sorunları. III. Halk sağlığı günleri Kongre Kitapçı̆̆ı. Kayseri 1993: 10-12.

29. Mazıcıoğlu M M, Öztürk A. Üniversite 3 ve 4. Sınıf Öğrencilerinde Beslenme Alışkanlıkları Ve Bunu Etkileyen Faktörler Erciyes Tip Dergisi (Erciyes Medical Journal), 2003; 25 (4):172178. 